\title{
Effects of doxorubicin associated with amniotic membrane stem cells in the treatment of canine inflammatory breast carcinoma (IPC-366) cells
}

Jéssica Borghesi ${ }^{1 *}$, Sara Caceres², Lara Carolina Mario ${ }^{1}$, Angela Alonso-Diez³, Ana Carolina Silveira Rabelo ${ }^{1}$, Maria J. Illera², Gema Silvan², Maria Angélica Miglino', Phelipe O. Favaron', Ana Claudia O. Carreira ${ }^{1,4^{*}}$ and Juan Carlos Illera²

\begin{abstract}
Background: Tumours in mammary glands represent the most common neoplasia in bitches, as in humans. This high incidence results in part from the stimulation of sex hormones on these glands. Among mammary tumours, inflammatory carcinoma is the most aggressive, presenting a poor prognosis to surgical treatment and chemotherapy. One of the most widely used chemotherapy drugs for breast cancer treatment is doxorubicin (DOXO). Alternative therapies have been introduced in order to assist in these treatments; studies on treatments using stem cells have emerged, since they have anti-inflammatory and immunomodulatory properties. The aim of this study was to evaluate the effects of DOXO and canine amniotic membrane stem cells (AMCs) on the triple-negative canine inflammatory mammary carcinoma cell line IPC-366.

Methods: Four experimental groups were analysed: a control group without treatment; Group I with DOXO, Group II with AMC and Group III with an association of DOXO and AMCs. We performed the MTT assay with DOXO in order to select the best concentration for the experiments. The growth curve was performed with all groups (I-III) in order to verify the potential of treatments to reduce the growth of IPC-366. For the cell cycle, all groups (I-III) were tested using propidium iodide. While in the flow cytometry, antibodies to progesterone receptor (PR), estrogen receptor (ER), PCNA, VEGF, IL-10 and TGF- $\beta 1$ were used. For steroidogenic pathway hormones, an ELISA assay was performed.

*Correspondence: jehborghesi@hotmail.com; anaclaudiaoli@gmail.com

'Department of Surgery, School of Veterinary Medicine and Animal Science, University of Sao Paulo, Sao Paulo, Brazil

Full list of author information is available at the end of the article

(c) The Author(s). 2020 Open Access This article is licensed under a Creative Commons Attribution 4.0 International License, which permits use, sharing, adaptation, distribution and reproduction in any medium or format, as long as you give appropriate credit to the original author(s) and the source, provide a link to the Creative Commons licence, and indicate if changes were made. The images or other third party material in this article are included in the article's Creative Commons licence, unless indicated otherwise in a credit line to the material. If material is not included in the article's Creative Commons licence and your intended use is not permitted by statutory regulation or exceeds the permitted use, you will need to obtain permission directly from the copyright holder. To view a copy of this licence, visit http://creativecommons.org/licenses/by/4.0/ The Creative Commons Public Domain Dedication waiver (http://creativecommons.org/publicdomain/zero/1.0/) applies to the data made available in this article, unless otherwise stated in a credit line to the data. 


\begin{abstract}
(Continued from previous page)
Results: The results showed that cells treated with $10 \mu \mathrm{g} / \mathrm{mL}$ DOXO showed a $71.64 \%$ reduction in cellular growth after $72 \mathrm{~h}$ of treatment. Reductions in the expression of VEGF and PCNA-3 were observed by flow cytometry in all treatments when compared to the control. The intracellular levels of ERs were also significantly increased in Group III (4.67\% vs. $27.1 \%)$. Regarding to the levels of steroid hormones, significant increases in the levels of estradiol (E2) and estrone sulphate (S04E1) were observed in Groups I and III. On the other hand, Group II did not show differences in steroid hormone levels in relation to the control. We conclude that the association of DOXO with AMCs (Group III) promoted a reduction in cell growth and in the expression of proteins related to proliferation and angiogenesis in IPC366 triple-negative cells.
\end{abstract}

Conclusions: This treatment promoted ER positive expression, suggesting that the accumulated oestrogen conducted these cells to a synergistic state, rendering these tumour cells responsive to ERs and susceptible to new hormonal cancer therapies.

Keywords: Amniotic membrane, Breast cancer, Co-culture, Dog, Therapy

\section{Background}

The development of tumour cells arises from a series of sequential mutations resulting from genetic instability. A more recent study has shown that the influence of environmental factors on healthy cells can generate these mutations, resulting in the formation of tumours [1].

Tumours in canine mammary glands represent the most common neoplasm in female dogs [2]. These types of tumours in female dogs are very similar to tumours presented in humans regarding their biological behaviour, their response to cytotoxic agents and their histological characteristics, but their incidence rate is three times higher than in women [3]. This high incidence results in part from the stimulation by sex hormones of the mammary glands of female dogs and women exposed to them during their reproductive life [4]. This hypothesis is supported by the expression of estrogen and progesterone receptors; it is possible that they act as promoting factors, stimulating cell proliferation, but not acting as initiating factors. However, when acting together in combination with other factors, for example, environmental and epigenetic factors at different stages of tumour formation, it is possible that they play a determining role in tumour formation [5].

Among breast tumours, we can highlight inflammatory breast carcinoma (IBC) as the most aggressive neoplasm found, affecting both women and female dogs [6]. Inflammatory breast cancer is characterised pathologically by rapid progression. Although this cancer is the less frequent type of breast neoplasia, representing only 2$4 \%$ of total breast cancers in the US, it has the highest mortality rate [7]. Nowadays, triple-negative breast carcinoma remains a major challenge for both human and veterinary medicine in terms of diagnosis and treatment [8]. Caceres et al. 2015 [9] established the first canine inflammatory mammary carcinoma cell line, named IPC366 , with an epithelial phenotype and the triple-negative expressions of estrogen receptor (ER), progesterone receptor (PR) and human epidermal growth factor receptor 2 (HER-2). This newly established cell line maintains the same features in vivo and exhibits vasculogenic mimicry properties in vitro and in vivo. Usually, mammary cancer treatment in canine species is based on removal of the tumour and mammary chain, followed by adjuvant chemotherapy after surgical treatment in order to eradicate possible micrometastases and increase the survival of the animal [10]. However, this treatment is contraindicated in cases of inflammatory carcinoma due to the extensive cutaneous involvement and its association with coagulopathies [11]. Nevertheless, conventional chemotherapy alone is not effective. Authors have been studying alternative treatments of canine mammary cancer, such as the association of the drug doxorubicin (DOXO) with peroxidam [12]. Many other agents are used in other tumour types, such as the association of stem cells, which can reduce the size of the tumour or extend the survival of the organism [13].

Recently, there has been an increasing interest in stem cell studies, specifically of foetal stem cells. These cells have a great capacity for proliferation and expansion in vitro [14]. Furthermore, due the fact that they are found in the foetal-maternal interface, they are immunologically tolerated, making them a safe choice for use in transplants and cell therapy. Several transplant and graft studies have been performed with human amniotic membrane at term, and their results have demonstrated that these cells do not cause an immune response [15]. This lack of immunogenicity can be explained by the immunomodulatory properties possessed by foetal membranes, which are involved in maternal-foetal maintenance and tolerance [16]. Several mechanisms assist these characteristics, such as the function of the amniotic membrane to secrete antiinflammatory proteins and its pro-apoptotic activity that promotes leukocyte apoptosis [17].

Consequently, the aim of this study was to evaluate the efficiency of amniotic membrane stem cells in 
association with drug treatments in canine mammary inflammatory carcinoma cell line.

\section{Methods}

Canine inflammatory mammary carcinoma cell line IPC-366 IPC-366 was obtained from the Department of Physiology of the Faculty of Veterinary Medicine of the Universidad Complutense de Madrid, which was previously characterised by Caceres et al. 2015 [9]. The cells were cultured in Dulbecco's Modified Eagle Medium Nutrient Mixture F-12 Ham (DMEM/F12; Sigma-Aldrich, D6421) supplemented with $5 \%$ foetal bovine serum (FBS; SigmaAldrich, 12103C), 1\% penicillin-streptomycin (SigmaAldrich, P0781) and 1\% L-glutamine (Sigma-Aldrich, G7513), in $25 \mathrm{~cm}^{3}$ flasks and maintained at $37{ }^{\circ} \mathrm{C}$, with relative humidity close to $100 \%$ and a gas atmosphere of $5 \% \mathrm{CO}_{2}$.

\section{Culture of the canine amniotic membrane stem cells}

The canine amniotic membrane stem cells (AMCs) were obtained in a neutering campaign by the collection of pregnant uterus during hysterectomy, as approved by the Ethics Committee for Animal Use (CEUA) School of Veterinary Medicine and Animal Science, University of Sao Paulo, FMVZ-USP: PROEX329/15. Cell isolation was carried out according to Uranio et al. 2011 [18] and Park et al., 2012 [19]. These cells had previously been characterised by Borghesi et al. 2019 [20]. Cell culture was carried out at the FMVZ-USP. The AMCs were maintained in the same IPC-366 medium and culture conditions.

\section{Interaction assay through cell co-culture}

For the interaction assay co-culture, the cells were seeded in 6-well transwell plates (Corning Inc, NY, USA). The AMCs $\left(3 \times 10^{4}\right.$ cells $)$ were seeded into the upper chamber of the transwells, while the IPC-366 cells $\left(5 \times 10^{4}\right.$ cells $)$ were incubated in the lower compartments. Cell treatments were carried out at 24, 48 and $72 \mathrm{~h}$ and divided into three experimental groups: Group I, IPC-366 treated with DOXO $(10 \mu \mathrm{g} / \mathrm{mL})$; Group II, IPC-366 treated with AMCs; and Group III, IPC-366 treated with an association of DOXO $(10 \mu \mathrm{g} / \mathrm{mL})$ and AMCs. A control group of IPC-366 cells without treatment was used in all experiments.

\section{Doxorubicin dosage determination}

To determine sensitivity of IPC-366 cells to the cytotoxic effect of DOXO (Sigma-Aldrich, D1515), four different final concentrations, $1,2,5$ and $10 \mu \mathrm{g} / \mathrm{mL}$, were used to determine the critical concentration to be used in the MTT assays.

\section{Cell metabolism assay (MTT)}

A total of $1 \times 10^{3}$ IPC-366 cells per well were seeded in 96-well plates and, after their adhesion, different concentrations of DOXO were added. MTT analysis was performed after 24, 48 and $72 \mathrm{~h}$. On each day of experiment, the culture medium was removed, then $10 \mu \mathrm{L}$ of MTT solution (M5655, Sigma) was added and incubated for $2 \mathrm{~h}$ at $37^{\circ} \mathrm{C}$ in the dark. After this period, MTT solution was aspirated from the wells and the remaining formazan crystals dissolved in $100 \mu \mathrm{L}$ of dimethyl sulfoxide (DMSO) (Sigma, M5655) and the absorbance measured at $490 \mathrm{~nm}$ in a spectrophotometer (MQuant- Bio Tek Instruments, VT, USA).

\section{Morphological analysis}

For the morphological analysis cells were observed under an inverted microscope (NIKON ECLIPSE TS$100)$ every day of treatment, in order to verify the morphological changes.

\section{Growth curve}

Approximately $2 \times 10^{4}$ IPC-366 cells were cultured in 6well plates (CLS3335, Sigma), and treated for $72 \mathrm{~h}$. Every $24 \mathrm{~h}$, three wells of each treatment and three control wells were counted with trypan blue to evaluate the cell growth.

\section{Cell cycle}

For cell cycle analysis, cells were subcultured, washed with phosphate saline buffer (PBS) and fixed in $70 \%$ ethanol overnight at $4{ }^{\circ} \mathrm{C}$. Cells were then treated with $40 \mathrm{mg} / \mathrm{mL}$ of propidium iodide (PI), $100 \mathrm{ug} / \mathrm{mL}$ (RNaseA, Sigma) and the samples analysed in a flow cytometer (FACSAriaII Cell Sorter, Becton Dickinson, San Jose, California, USA) and analysed by software Modfit 2.9.

\section{Flow cytometry}

Immunophenotypic analysis was performed using flow cytometry. For this, $1 \times 10^{5}$ cells $/ \mathrm{mL}$ were trypsinised, centrifuged and fixed in $4 \%$ of paraformaldehyde. The cells were then incubated with primary antibodies (dilution 1:100) for $30 \mathrm{~min}$ at $4{ }^{\circ} \mathrm{C}$. After this period, the cells were incubated with the secondary antibody (dilution 1: 500) for $30 \mathrm{~min}$ at $4{ }^{\circ} \mathrm{C}$. Finally, the cells were washed and analysed by a BD FACSAriaII Flow Cytometer (Becton Dickinson, San Jose, CA, USA). Controls were performed using unmarked cells exposed only to the nonspecific secondary antibody. For each sample, 10,000 events were counted. The primary antibodies used were as follows: Anti-VEGF (ab1316, Abcam, Cambridge, UK), Anti-PCNA-3 (sc-46, Santa Cruz Biotechnology Inc, Europe), Anti-PR (ab-2764, Abcam, Cambridge, UK), anti-ER (ab2746, Abcam, Cambridge, UK), antiTGF- $\beta 1$ (sc-146, Santa Cruz Biotechnology Inc, Europe) and anti-IL-10 (MCA2111B, AbD Serotec, California, 
USA). The secondary antibodies used were anti-mouse (ab150115, Abcam, Cambridge, UK) and anti-rabbit (ab150079, Abcam, Cambridge, UK), and analysed by software FlowJo 10.

\section{Steroid hormone analysis}

The culture medium of control and treated cells were collected and frozen at $-20{ }^{\circ} \mathrm{C}$ until hormone analysis. The levels of hormones were measured by immunoenzymatic assay (ELISA), previously validated by Illera et al., 2016 [21]. Steroid hormones tested were estrone sulphate (SO4E1: ab R522-2), estradiol (E2: C6E91), androstenedione (A4: ab C9111), testosterone (T: R156), dihydrotestosterone (DHT: C1D4), dehydropeiandrosterone (DHEA: C9411), progesterone (P4: C914) and pregnenolone (P5: C1P53). All antibodies were developed in the Department of Animal Physiology (UCM, Spain). All hormone concentrations are expressed in $\mathrm{ng} / \mathrm{mL}$. Three independent experiments were performed.

\section{Statistical analysis}

The results obtained from the hormonal analysis were submitted to the two-way ANOVA followed by the
Bonferroni post-hoc test. For this analysis, the software used was Graph Pad Prism version 5.0. Statistically significant differences were considered when $p<0.05$.

\section{Results}

Doxorubicin treatment on proliferation of IPC-366 cells

To establish the optimal chemotherapeutic dosage of IPC-366 cells, distinct concentrations of DOXO (1, 2, 5 and $10 \mu \mathrm{g} / \mathrm{mL}$ ) were tested by the MTT colorimetric method. The $10 \mu \mathrm{g} / \mathrm{mL}$ dosage showed the highest efficacy in the treatment of IPC-366, with a reduction of $22.76 \%$ after $24 \mathrm{~h}, 50.76 \%$ at $48 \mathrm{~h}$ and $71.64 \%$ at $72 \mathrm{~h}$. (Fig. 1a-c). Therefore $10 \mu \mathrm{g} / \mathrm{mL}$ dosage was chosen to be used during treatment.

\section{Analysis of growth curve and morphology}

First of all, cell growth was observed through the growth curve. In the Group I, the cells showed a continuous decrease in growth, differing from the control group. Although Group II showed cell growth over $72 \mathrm{~h}$, there was still less growth than the control group. In Group III, the growth curve showed discrete growth until $48 \mathrm{~h}$ compared to control. After this period, there was a decline in growth (Fig. 1d).
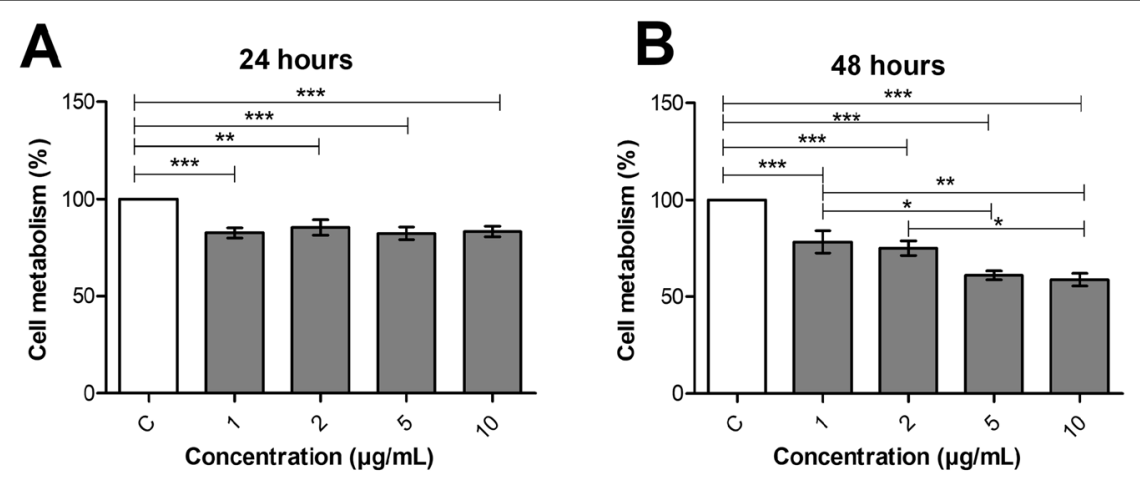

C

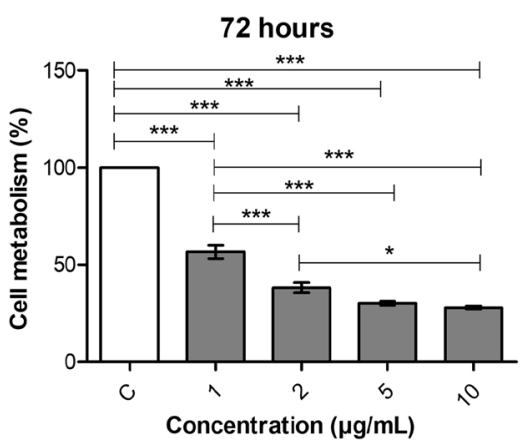

D

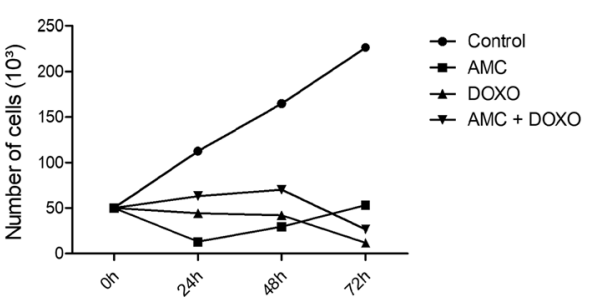

Fig. 1 Cell metabolism assay by MTT analysis of IPC-366 control cells and those treated with 1-10 $\mu \mathrm{g} / \mathrm{mL}$ of DOXO for 24 (a), 48 (b) and $72 \mathrm{~h}$ (c). Growth curve analysis was evaluated in 24 h, 48 h, and 72 h (d). DOXO: doxorubicin; AMCs: amniotic membrane cells. Data are averaged ( $n \geq$ $04 \pm$ SEM), performed with one-way analysis of variance (ANOVA) as a Bonferroni pos-hoct test, ${ }^{*} p<0.05,{ }^{* *} p<0.01,{ }^{* *} p<0.001$ 
Morphological changes in the cells during the different treatments were also observed. Analysing the control cells during the 72-h period, the epithelial shape remained and a confluence, with the appearance of interlaced cells, formed a cellular cluster (Fig. 2a-c). Group I at $24 \mathrm{~h}$ maintained the same epithelial morphology as control; however, after $48 \mathrm{~h}$ the cells lost their original shape becoming rounded and irregular (Fig. 2d-f). In Group II, cells maintained their epithelial morphology with the same characteristics as the control during treatment (Fig. 2g-i). In Group III after $48 \mathrm{~h}$ only a few cells began to lose their original morphology, differing from Group I, where virtually all cells lost their original format, showing an irregular shape (Fig. 2j-1).

\section{Cell cycle analysis}

By cell cycle analysis it was possible to determine at which phase of the cycle the cells were during each treatment. In Group I, most of the cells were arrested in the GO/G1 phase (cellular interphase) throughout $48 \mathrm{~h}$ compared to control group. In Group II, the cells presented distinct peaks at each treatment time: at $24 \mathrm{~h}$ the greatest number of cells were expressed in $\mathrm{G} 2 / \mathrm{M}$, at $48 \mathrm{~h}$ in phase $\mathrm{S}$ and at $72 \mathrm{~h}$ in phase GO/G1. In Group III, at $24 \mathrm{~h}$ the cells were in $\mathrm{G} 2 / \mathrm{M}$, at $48 \mathrm{~h}$ the largest population was in GO/G1 and at $72 \mathrm{~h}$ in phase $\mathrm{S}$ (Fig. 3a-c).

\section{Flow cytometry results}

The expression of proteins present in IPC-366 after the treatments was determined by flow cytometry analysis.

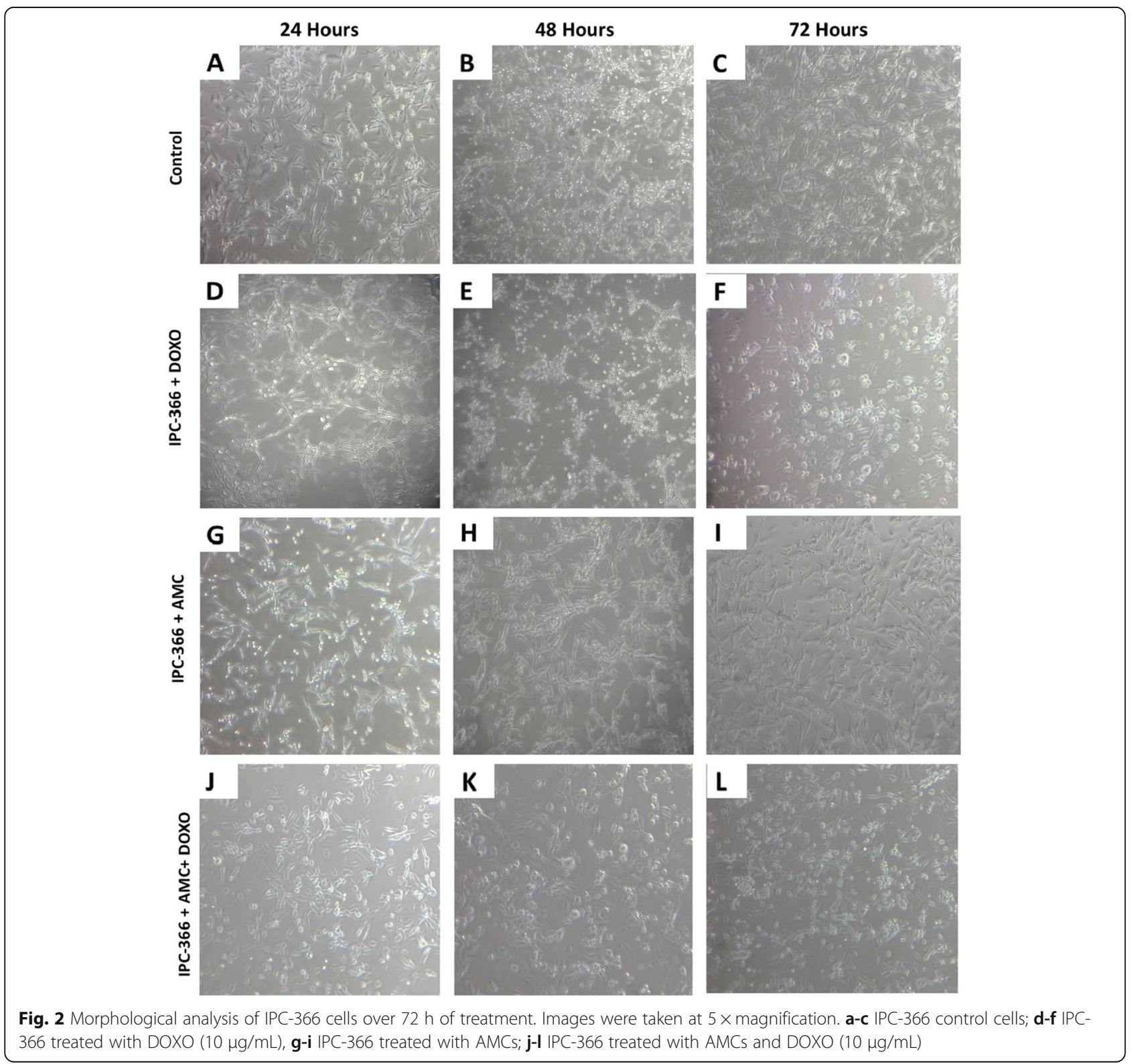




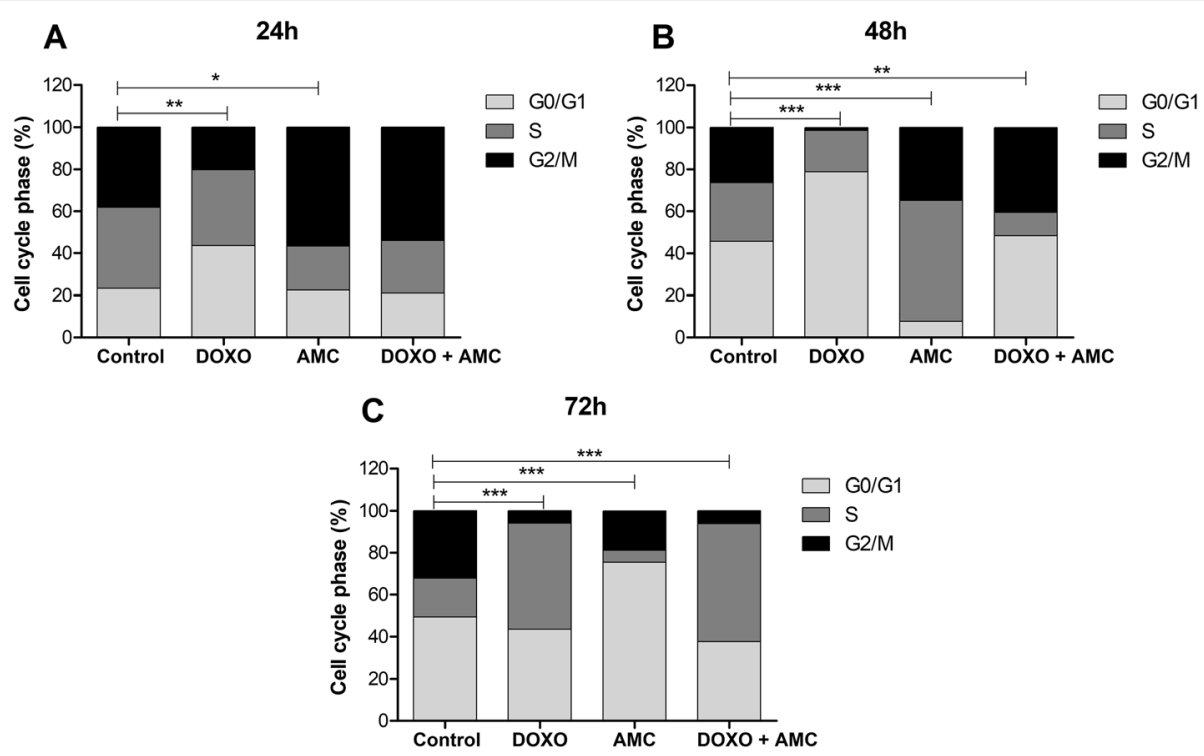

Fig. 3 Cell cycle analysis at $24(\mathbf{a}), 48$ (b) and 72 h (c), showing the percentage of cells in the interphase (G0/G1), DNA replication phase (S) and cell division (G2M). Data are averaged ( $n \geq 03 \pm$ SEM). Comparisions against control were performed by Chi-square analysis, ${ }^{*} p<0.05,{ }^{* *} p<0.01,{ }^{* * *} p<0.001$

Regarding the expression of PR, it was observed that control cells presented low expression (5.4\%). However, Group II showed an even more significant reduction (0.9\%). On the other hand, Group III showed an increase in PR expression, although it was not significant (Fig. 4a). Regarding ER, we observed an increase in its expression in Groups II and III, and in the association of DOXO with AMC the increase was approximately 10-fold higher than in the control group (Fig. 4b). In relation to the expression of VEGF, all treatment groups were effective in reducing its expression (Fig. 4c). A reduction in PCNA expression was observed in all treated groups (I-III; Fig. 4d). Regarding interleukin-10, we observed a reduction in its expression in Groups I and III (Fig. 4e). Finally, TGF- $\beta$ was also analysed, and results showed low expression in control cells (8.9\%), whereas in Group III, TGF- $\beta 1$ expression was higher than in control (26.9\%; Fig. 4f).

\section{Steroid hormone concentrations in culture medium}

The steroid hormone levels presented in the culture medium of IPC-366-treated cells were analysed by ELIS A. In Group I it was possible to observe a significant increase $(p<0.05)$ in P4, A4, E2 and SO4E1 levels, and a reduction in DHEA and DHT levels $(p<0.05)$ in relation to the control group. In Group II, a significant increase $(p<0.05)$ was observed only in P4 and DHT levels, showing that the treatment was not sufficient to cause alterations in steroid hormone concentrations. Finally, treatment in Group III significantly reduced $(p<0.05)$ the androgens DHEA and DHT, whereas there was an increase in the estrogen levels $(p<0.05)$ E2 and SO4E1 (Fig. 5).

\section{Discussion}

One of the most effective chemotherapeutic agents used for the treatment of haematological and solid tumours is doxorubicin [22]. Nevertheless, many types of tumour exhibit multidrug resistance, which may lead to a decrease in its effectiveness after a favourable initial response [23]. In our in vitro results we found that the optimal dosage of DOXO in treating IPC-366 cells was $10 \mu \mathrm{g} / \mathrm{mL}$, resulting in a reduction in proliferation and cell growth of up to $72.46 \%$ after $72 \mathrm{~h}$ of treatment. This same dosage was used to treat the triple-negative adenocarcinoma cell line MDA-MB-231, where DOXO caused a 50\% growth reduction after $24 \mathrm{~h}$ [24], demonstrating lower drug resistance when compared to IPC-366, which demostrated a growth reduction of $16.76 \%$ after $24 \mathrm{~h}$. However, given that IPC-366 has been described as an aggressive tumour cell line [9], DOXO caused a reduction in cell growth, demonstrating that this drug can provide effective antitumor activity in canine mammary cancer. Currently, resistance to chemotherapy represents the biggest obstacle to success in the treatment of human and canine breast cancer [25].

The IPC-366 control cells presented an epithelial morphology as described by Caceres et al., 2015 [9]. In this work, during treatment with AMCs it was possible to verify that, despite all the factors released by the AMCs, they did not influence the cell morphology; however, after treatment with DOXO they did show cellular alterations, such as cell membrane rupture and a 

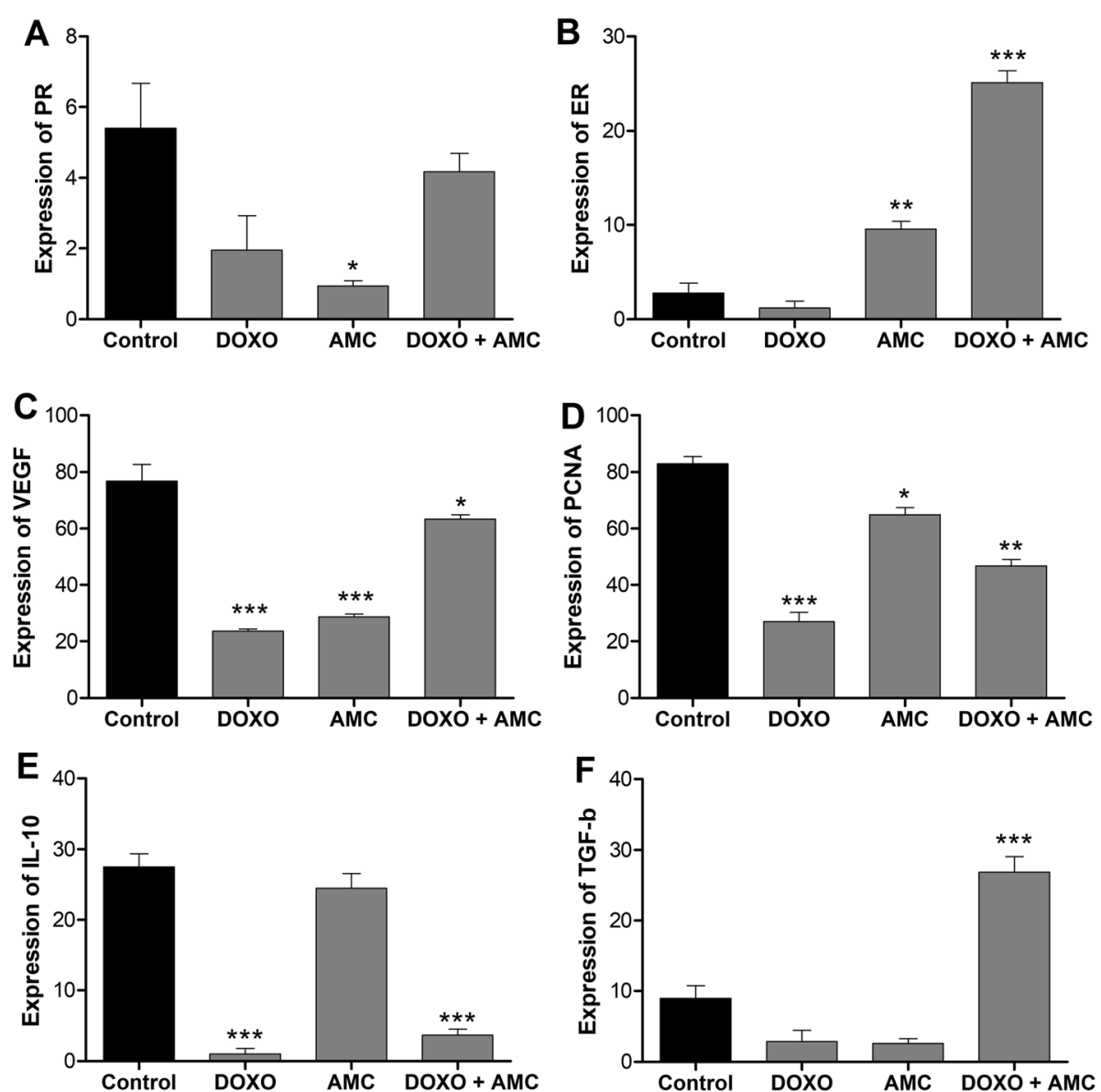

Fig. 4 Cell marker expression (\% of cells) by flow cytometry of control and cells treated with doxorubicin (DOXO, $10 \mu \mathrm{g} / \mathrm{mL})$; amniotic membrane stem cells (AMCs); and DOXO + AMC. a Progesterone receptor (PR), b Estrogen receptor (ER), (c) VEGF, (d) PCNA-3, (e) IL-10, (f) TGF- $\beta 1$. Data are averaged $(n \geq 04 \pm$ SEM) of expression. (\%). Comparisions against control were performed with one-way analysis of variance (ANOVA) as a Bonferroni post-hoc test, ${ }^{*} p<0.05,{ }^{* *} p<0.01,{ }^{* * *} p<0.001$

rounded shape, indicating cellular apoptosis. This is in accordance with other studies that tested the effect of this drug on tumour cells [26].

Tumor cells are characterised by uncontrolled growth and cell proliferation [27]; one mechanism of ascertaining the effectiveness of anticancer treatments is their role in interrupting the cell cycle [28]. Doxorubicin is a non-specific agent of the cell cycle, acting in the phases of division and rest. However, its main cytotoxic action is observed during the $\mathrm{S}$ phase of the cell cycle, by altering the DNA structure and producing free radicals that help fight cancer [29]. These effects were found in this study for Groups I and III, where the majority of cells were found in the $\mathrm{S}$ phase after $72 \mathrm{~h}$ of DOXO treatment. However, in Group II, treatment with AMCs, it was found that the cells were in the GO/G1 interphase. This can be explained by the release of cytokines by mesenchymal stem cells. These cytokines are capable of inducing cell cycle arrest in tumour cells [30].
Sex steroid hormones, especially estrogens, play a key role in mammary carcinogenesis in mammals, including female dogs [31]. An important predictor for breast cancer is the evaluation of the ER and PR expression profile, which allows clinicians to predict the response of breast cancer to treatment [32]. If a higher ER and PR expression is observed in the tumour, there is a greater probability of response to hormone therapy [33]. Therefore, the response rate to the treatment of patients classified as $\operatorname{ER}(-)$ and $\operatorname{PR}(-)$ is only $10 \%$. This rate increase to $40 \%$ [34] in ER(+) and PR(-) patients. IPC-366 cells were characterised as negative for ER and PR expression, and after treatment with DOXO and AMCs (Group III), a reversal in their expression was observed. The cells returned a positive phenotype for ER with a percentage expression of $25 \%$ and remained negative for PR with a percentage of $4.17 \%$.

In addition to the hormone receptors, other proteins were also evaluated, such as the VEGF involved in tumour angiogenesis. Results showed a lower rate of 


\section{A Pregnenolone-P5}

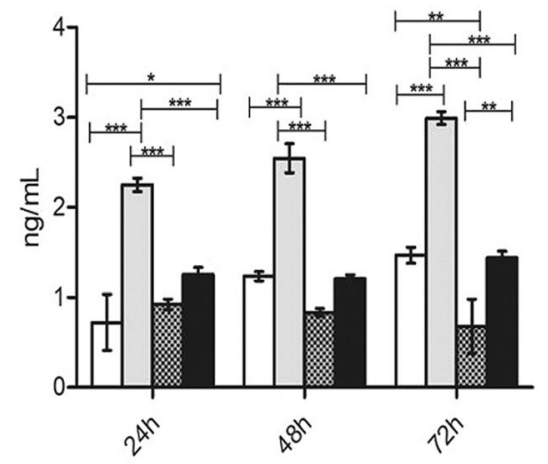

C Dehydropeiandrosterone-DHEA

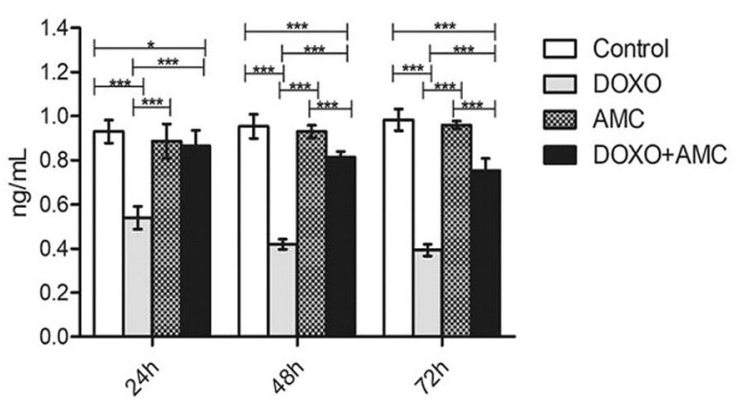

E Dihydrotestosterone-DHT

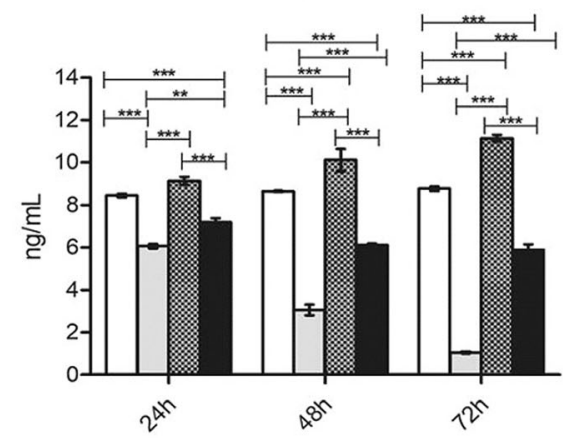

G

Estradiol-E2

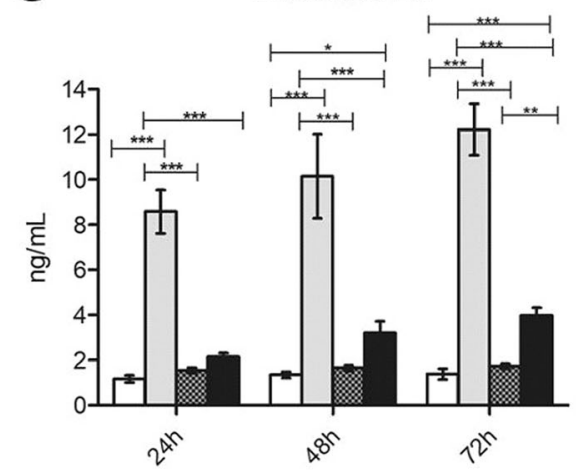

B

Progesterone-P4
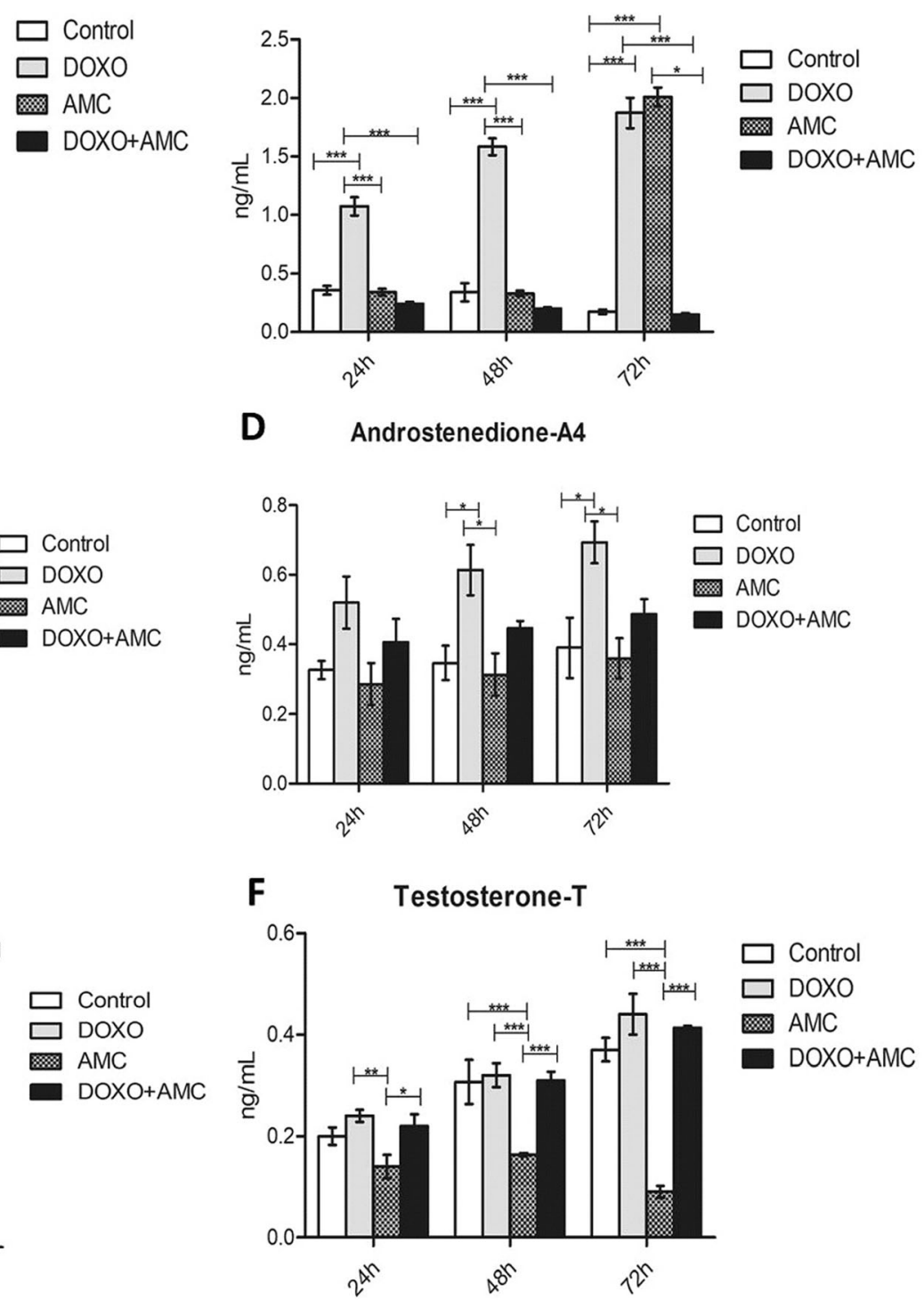

H Estrone sulphate-SO4E1

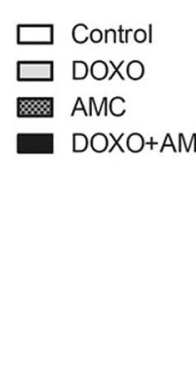

Fig. 5 (See legend on next page.) 
(See figure on previous page.)

Fig. 5 Steroid hormone levels in culture medium of IPC-366 control and treated cells. Graphs show hormone concentrations of pregnenolone (P5) (a), progesterone (P4) (b), dehydroepandrostenedione (DHEA) (c), androstenedione (A4) (d), dihydrotestosterone (DHT) (e), testosterone T (f), estradiol (g), estrone sulphate (SO4E1) (h) through the treatment period (24, 48 and 72 h). Treated groups (DOXO, AMC and DOXO + AMC, DOXO: $10 \mu \mathrm{g} / \mathrm{mL}$ ) were compared to control group over the treatment period. The results presented as the mean \pm SEM of 3 ndependent experiments $\left({ }^{*} p<0.05 ;{ }^{* *} p<0.01 ;{ }^{* * *} p<0.001\right)$. DOXO: doxorubicin; AMCs: canine amniotic membrane stem cells

expression in the DOXO treatment, demonstrating a beneficial effect of the chemotherapy. The inhibition of VEGF reduces the abnormality of the vessels and increases the tumour permeability to chemotherapy [35]. This reduction was also observed for the protein PCNA, which was highly expressed in the IPC-366 cell line and, after all treatments, a significant reduction in its expression was observed. This reduction in PCNA expression with DOXO treatment can be explained by its role in the inhibition of topoisomerase II, which induces DNA breakage, inhibiting its replication [36]. Since amniotic membrane-derived cells have antiproliferative effects, they can arrest the cell cycle in the G0/G1 phase due to unknown factors [37]. These factors, produced by amniotic stem cells, can regulate the expression of cancer cell proteins associated with the cell cycle, such as cyclindependent kinases (CDK2, CDK4, CDK6) and cyclins (cyclin D2, cyclin E1, cyclin H).

Our analyses showed that the lowest expression of the interleukin IL-10 occurred when DOXO was used, whether or not associated with AMCs. This drug contributed to the reduction of the inflammatory and immunosuppressive responses, promoting a favourable microenvironment for an immune response to the tumours. This is in accordance with Nugroho et al. (2012) [38], who verified the immunosuppressive effects of DOXO.

Another molecule involved in signalling pathways in breast cancer is TGF- $\beta$, which can induce epithelialmesenchymal transition; its expression can be influenced negatively by oestrogen levels. ER- $\alpha$ inhibits TGF- $\beta$ signalling by decreasing Smad protein levels. High estrogen levels cause a suppression in the levels of TGF- $\beta 1$ [39]. This could also be observed in our treatments, since Groups I and II, which did not present estrogen expression, were also absent for TGF- $\beta$, unlike Group III, which presented expression for estrogen and consequently for TGF- $\beta$.

On the other hand, the normal activity of the normal cells depends on the perfect integration between its metabolic pathways, which is mainly controlled by the steroid hormones [40]. These hormones, among other factors, induce or promote carcinogenesis by stimulating cellular proliferation [41]. It is known that there are two steroidogenic pathways for the production of steroid hormones, both presenting cholesterol as a precursor molecule [42]. First, cholesterol is converted to P5, which is the first hormone of the steroidogenic cascade and precursor of the hormones DHEA and P4. In one of the steroidogenic pathways, androgens are formed from the conversion of P5 into DHEA, which leads to the formation of A4. On the other pathway, P5 is initially converted to $\mathrm{P} 4$, which is consequently converted to $\mathrm{A} 4$, an androgen precursor. The first pathway is known as the $\Delta 5$ pathway, and the second the $\Delta 4$ pathway [43]. A4 can be converted into $\mathrm{T}$, which is the precursor hormone of DHT. Indeed, A4 can be converted directly to estrogens by the conversion of A4 to estrone (E1) and subsequently in SO4E1. Finally, testosterone can also give rise to estrogens, resulting in the production of E2 [44]. Therefore, neoplastic cells can experience an imbalance in the steroidogenic pathways. Because of this, hormone production is one of the targets of therapies for the treatment of various neoplasms, especially breast cancer $[45,46]$. For this reason, our study evaluated the interference of treatments in the levels of the main steroid hormones.

In Group I, treated with DOXO, we observed that no interference occurred in estrogen pathways, since E2 and SO4E1 levels were increased at the end of the treatment period. However, DHEA was at low levels, indicating inhibition of the $\Delta 5$ pathway, which is the preferred steroidogenic pathway in IBC [47]. Other in vitro studies also measured these hormones after treatment with androgen inhibitors with similar results to our DOXO treatment by choosing the $\Delta 5$ pathway [48]. The results obtained by hormonal analysis, where the presence of oestrogen production was verified, are due to the data obtained in the analysis of flow cytometry. The absence of ERs was observed and, although the steroid hormones could enter the cells through the membrane [49], they could be accumulated in the medium and thus promote no functional effects on IPC-366 cells. Steroid hormone receptors depend on intracellular transcription factors that mediate their biological actions [50]. Besides that, receptors are responsible for hormone signalling transduction to the target genes, interacting with specific DNA sequences and several regulatory proteins including activators or co-repressors [45]. Therefore, the absence of receptor expression causes the continuity of malignancy in this type of carcinoma.

In Group II, treatment with AMCs did not interfere at all stages of the steroidogenic metabolism of IPC-366 cells. The results suggest that P5 reduction may have occurred because of its total conversion to progesterone 


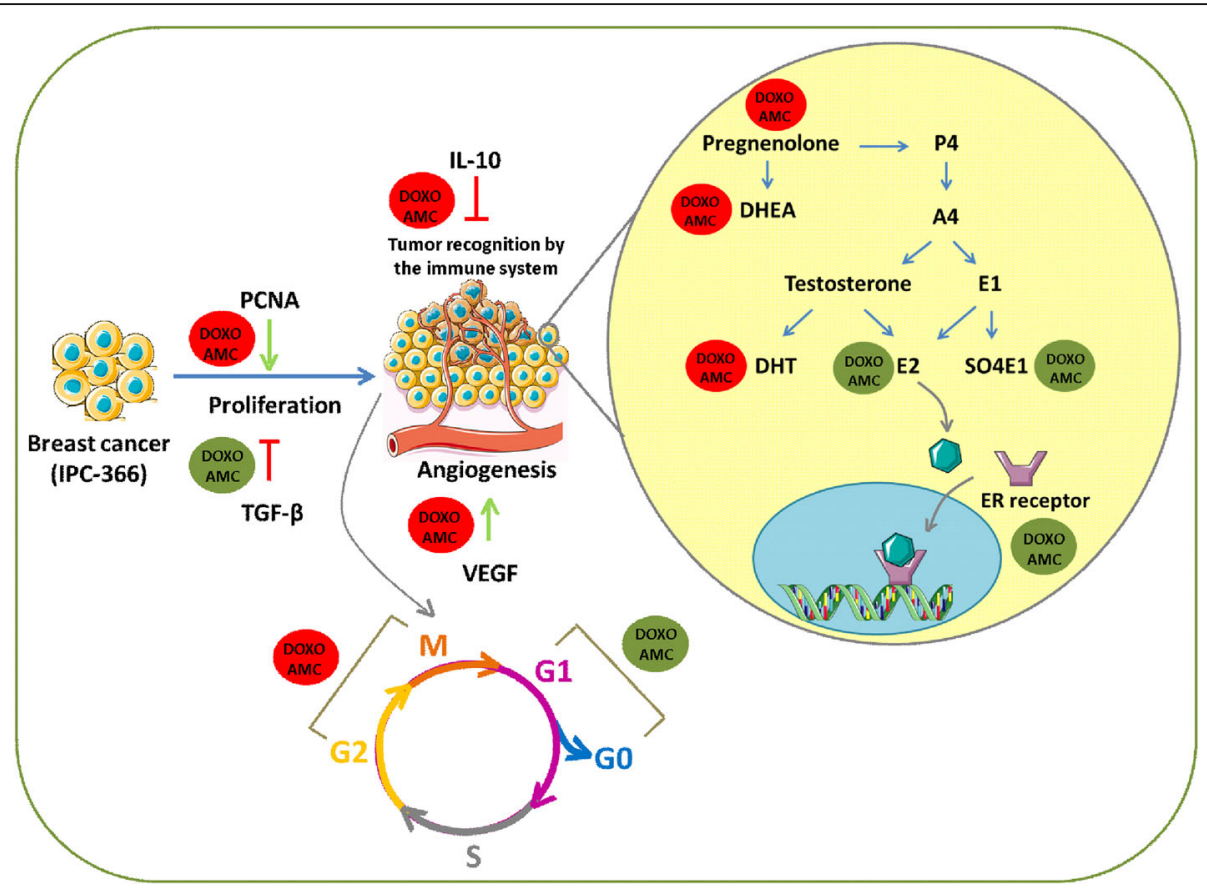

Fig. 6 Scheme of the main effects of the treatment with doxorubicin (DOXO) and canine amniotic membrane cells (AMCs) in IPC-366 cells. The proliferation and angiogenesis of IPC-366 cells were increased due to the influence of PCNA, TGF- $\beta 1$ and VEGF; however, treatment with DOXO + AMC association reversed this situation. Moreover, the treatment with the DOXO + AMC decreased IL-10 levels, which may have allowed tumour cells to be recognised by the components of the immune system and to decrease the inflammatory process. In addition, after treatment with $\mathrm{DOXO}+\mathrm{AMC}$ there was an increase of cells in the G1/G0 phase and decrease in those in the G2/M phase due to a reduction in cell duplication. Furthermore, after treatment with the combination, there were reductions in the levels of P5, DHEA and DHT, while there were increases in E2 and SO4E, important steroid hormones in the steroidigenic pathway. We also observed that there was an increase in ER expression, which can be used as a therapeutic targetP4: progesterone; A4: androstenedione; E1: estrone

after the first $48 \mathrm{~h}$ of treatment; similar results were observed on $\mathrm{T}$ levels, which were reduced dramatically after $24 \mathrm{~h}$ of treatment, being fully converted into DHT. This DHT accumulation may suggest that AMC treatment may be effective in reducing the proliferation of breast cancer tumour cells, since this is the most potent androgen for this function [51], as other studies have observed for MCF-7, another breast cancer cell line [52].

Finally, in Group III (association of DOXO and AMCs), the treatment did not significantly alter the levels of the hormones of the $\Delta 4$ pathway, probably due to the low availability of P5 as a substrate. DHEA levels suffered a significant reduction, as occurred in Group I, which leads us to suppose that the AMCs exerted a modulatory effect on the hormonal production of the $\Delta 4$ pathway (Fig. 6).

\section{Conclusions}

The association of DOXO and AMCs has been shown, for the first time, to be an alternative and effective treatment for triple-negative tumours, since we found an increase in ERs, resulting in cells that could be susceptible to anti-estrogen therapy, allowing the application of hormone therapy in these tumours.

\section{Abbreviations}

A4: Androstenedione; AMC: Canine amniotic membrane stem cells: DHEA: Dehydropeiandrosterone; DHT: Dihydrotestosterone;

DOXO: Doxorubicin; E2: Estradiol; ER: Estrogen receptor; IBC: Inflammatory breast carcinoma; IPC-366: Triple-negative canine inflammatory mammary carcinoma cell line; P4: Progesterone; P5: Pregnenolone; PI: Propidium iodide; PR: Progesterone receptor; SO4E1: Estrone sulphate; T: Testosterone

\section{Acknowledgements}

Not applicable.

\section{Authors' contributions}

JB: Performed all the experiments, analysed and wrote the article. SC: Culture of IPC-366 cells and analysis of results. LC: Culture of AMC cells, analysis of results and writing. AAD: Culture of IPC-366, hormonal analysis and analysis of results. ACSR: Culture of AMC cells, analysis of results and writing. MJl: hormone analysis and analysis of results. GS: hormonal analysis and analysed of results. MAM: Culture of AMC cells, analysis of results and writing. POF: Culture of AMC cells, analysis of results and writing. ACOC: Culture of AMC cells, analysis of results and writing. JCl: Performed all the experiments, analysed and wrote the article. All authors have read and approved the final manuscript.

\section{Funding}

This work was supported by CAPES (Coordenação de Aperfeiçoamento de Pessoal de Nível Superior, Grant no 88881.131704/2016-01). The funding agency carried out the design and delimitation of the project.

\section{Availability of data and materials}

The datasets generated and/or analysed during the current study are not publicly available due to the data of characterisation of AMCs being at the 
writing stage of the manuscript for publication, but are available from the corresponding author on reasonable request.

\section{Ethics approval and consent to participate}

Ethics Committee for Animal Use (CEUA) School of Veterinary Medicine and Animal Science, University of Sao Paulo, FMVZ-USP: PROEX329/15.

\section{Consent for publication}

Not applicable.

\section{Competing interests}

The authors declare that they have no competing interests.

\section{Author details}

${ }^{1}$ Department of Surgery, School of Veterinary Medicine and Animal Science, University of Sao Paulo, Sao Paulo, Brazil. '2Department of Animal Physiology, School of Veterinary Medicine, Complutense University of Madrid (UCM), Madrid, Spain. ${ }^{3}$ Department of Animal Medicine, Surgery and Pathology, School of Veterinary Medicine, Complutense University of Madrid (UCM), Madrid, Spain. ${ }^{4}$ NUCEL (Cell and Molecular Therapy Center), School of Medicine, University of Sao Paulo, Sao Paulo, Brazil.

Received: 21 July 2020 Accepted: 15 September 2020

Published online: 24 September 2020

\section{References}

1. Schaefer MH, Serrano L. Cell type-specific properties and environment shape tissue specificity of cancer genes. Sci Rep. 2016;6:1-14.

2. Dutra AP, Granja NVM, Schmitt FC, Cassali GD. C-Erbb-2 expression and nuclear pleomorphism in canine mammary tumors: comparative aspects with human breast tumor. Braz J Med Biol Res. 2004;37:1673-81.

3. Moe L. Population-based incidence of mammary tumours in some dog breeds. J Reprod Fertil Suppl. 2001;57:439-43.

4. Farhat GN, Cummings SR, Chlebowski RT, Parimi N, Cauley JA, Rohan TE, et al. Sex hormone levels and risks of estrogen receptor-negative and estrogen receptor-positive breast cancers. J Natl Cancer Inst. 2011;103:562-70.

5. Misawa A, Inoue S. Estrogen-related receptors in breast cancer and prostate cancer. Front Endocrinol. 2015;6:1-7.

6. Peña L, Silván G, Pérez-Alenza MD, Nieto A, Illera JC. Steroid hormone profile of canine inflammatory mammary carcinoma: a preliminary study. J Steroid Biochem Mol Biol. 2003:84:211-6.

7. Wolbank S, Peterbauer A, Fahrner S, Van Griensuen M, Stadler G, Redl H, Gabriel C. Dose-dependent immunomodulatory effect of human stem cells from amniotic membrane: a comparison with human mesenchymal stem cells from adipose tissue. Tissue Eng. 2017;13:1173-83.

8. Yao H, He G, Yan S, Chen C, Song L, Rosol TJ, Deng Z. Triple-negative breast cancer: is there a treatment on the horizon? Oncotarget. 2017:8:1913-24.

9. Caceres S, Peña L, Andres PJ, Illera MJ, Lopez MS, Woodward MA, Reuben JM, Illera JC. Establishment and characterization of a new cell line of canine ilnflammatory mammary cancer: IPC-366. PLoS ONE. 2015;10:e0122277.

10. Rutteman GR, Withrow SJ, Macewen EG. Tumors of the mammary gland In: MacEwen GE, Whithrow SJ. Smal animal clinical oncology. 3ed, Saunders Company: 2001.p. 455-77.

11. Susaneck SJ, Allen TA, Hoopes J, Withrow SJ, Macy DW. Inflammatory mammary carcinoma in the dog. J Am Anim Hosp Assoc. 1983;9:971-6.

12. Marconato L, Romanelli G, Stefanello D, Giacoboni C, Bonfanti U, Bettini G, Finotello R, Verganti S, Valenti P, Ciaramella L, Zini E. Prognostic factors for dogs with mammary inflammatory carcinoma: 43 cases (2003-2008). J Am Vet Med Assoc. 2009:235:967-72.

13. Momin EN, Mohyeldin A, Zaidi HA, Vela G, Quiñones-Hinojosa A. Mesenchymal stem cells: new approaches for the treatment of neurological diseases. Curr Stem Cell Rest T. 2010;5:326-44.

14. Fernandes RA, Costola-Souza C, Sarmento CAP, Gonçalves L, Favaron PO, Miglino MA. Placental tissues as sources of stem cells-Review. OJAS. 2012; 2:166-73.

15. Wolbank S, Peterbauer A, Fahrner S, Van Griensuen M, Stadler G, Redl H, Gabriel C. Dose-dependent immunomodulatory effect of human stem cells from amniotic membrane: a comparison with human mesenchymal stem cells from adipose tissue. Tissue Eng. 2007;13:1173-83.

16. Parolini O. Human amnion mesenchyme harbors cells with allogeneic T-cell suppression and stimulation capabilities. Stem Cells. 2008;26:182-92.
17. Zhou S, Chen J, Feng J. The effects of amniotic membrane on polymorphonuclear cells. Chi Med J. 2003;116:788-90.

18. Uranio MF, Valentini L, Lange-Consiglio A, Caira M, Guaricci AC, L'Abbate A, Catachio CR, Ventura M, Cremonesi F, Dell'Aquila ME. Isolation, proliferation, cytogenetic, and molecular characterization and in vitro differentiation potency of canine stem cells from foetal adneza: a comparative study of amniotic fluid, amnion, and umbilical cord matriz. Mol Reprod Dev. 2011;78:361-73.

19. Park SB, Seo MS, Kim HS. Isolation and characterization of canine amniotic membrane-derived multipotente stem cells. Plos ONE. 2012;9:e44693.

20. Borghesi J, Lima MF, Mario LC, Anunciação ARA, Rabelo ACS, Silva MGKC, Fernandes FA, Miglino MA, Carreira ACO, Favaron PO. Canine amniotic membrane mesenchymal stromal/stem cells: Isolation, characterization and differentiation. Tissue Cell. 2019:58:99-106.

21. Illera JC, Caceres S, Peña L, de Andres PJ, Monsalve B, Illera MJ, Silvan G. Steroid hormone secretion in inflammatory breast cancer cell lines. Horm Mol Biol Clin Investig. 2015;24:137-45.

22. Butany J, Ahn E, Luk A. Drug-related cardiac pathology. J Clin Pathol. 2009; 62:1074-84

23. Gianni L, Herman EH, Lipshultz SE, Minotti G, Sarvazyan N, Sawyer DB. Anthracycline cardiotoxicity: from bench to bedside. J Clin Oncol. 2008;26: 3777-84.

24. Li P, Mao Z, Peng Z, Zhou L, Chen Y, Huang PH, Suresh S. Acoustic separation of circulating tumor cells. Proc Natl Acad Sci USA. 2015;112: 4970-5.

25. Smith DM, Murphy WM. Histologic changes in prostate carcinomas treated with leuprolide (luteinizing hormone-releasing hormone effect). Distinction from poor tumor differentiation. Cancer. 1994;73:1472-7.

26. Aniogo EC, George BPA, Abrahamse H. Phthalocyanine induced phototherapy coupled with Doxorubicin; a promising novel treatment for breast cancer. Expert Rev Anticancer Ther. 2017:17:693-702.

27. Hanahan D, Weinberg RA. Hallmarks of câncer: the next generation. Cell. 2011:4:646-7.

28. Sherr CJ. Cancer cell cycles. Science. 1996;274:1672-7.

29. Rodaski S, De Nardi RB. Quimioterapia antineoplásica em cães e gatos. Editora Maio 2004.p. 307

30. Cousin B, Ravet E, Poglio S, De Toni F, Bertuzzi M, Lulka H, et al. Adult stromal cells derived from human adipose tissue provoke pancreatic cancer cell death both in vitro and in vivo. Plos One. 2009; 4: e6278.

31. Silva AE, Serakides R, Cassali GD. Carcinogênese hormonal e neoplasias hormônio-dependentes. Cienc Rural. 2004;34:624-33.

32. Thorpe SM. Estrogen and progesterone receptor determinations in breast cancer. Technology, biology and clinical significance. Acta Oncol. 1988;27:1-19.

33. Hawkins RA. How best to express oestrogen receptor activity. Eur J Cancer. 2000;36:21-3.

34. Reiner A, Neumeister B, Spona J, Reiner G, Schemper M, Jakesz R Immunohistochemical localization of estrogen and progesterone receptor and prognosis in human primary breast cancer. Cancer Res. 1990;50:7057-61.

35. Ferrara N, Gerber HP, Lecouter J. The biology of VEGF and its receptors. Nat Med. 2003:9:669-76.

36. Lehmann M, Franco A, Vilar KDSP, Reguly ML, DE Andrade HHR Doxorubicin and two of its analogues are preferential inducers of homologous recombination compared with mutational events in somatic cells of Drosophila melanogaster. Mutat Res Genet Toxicol Environ Mutagen. 2003;539:167-75.

37. Magatti M, De Munari S, Vertua E, Parolini O. Amniotic membrane derived cells inhibit proliferation of cancer cell lines by inducing cell cycle arrest. J Cell Mol Med. 2002;16:2208-18.

38. Nugroho AE, Hermawan A, Putri PD, Meiyanto E, Hakim L. Synergistic effects of ethyl acetate fraction of Ficus septica Burm. f. and doxorubicin chemotherapy on T47D human breast cancer cell line. Zhong Xi Yi Jie He Xue Bao. 2012;10:1162-70.

39. Papageorgis P. TGF $\beta$ Signaling in tumor initiation, epithelial-tomesenchymal transition, and metastasis. J Oncol. 2015; 2015: 587193.

40. Guyton AC. Tratado de fisiologia médica. Guanabara Koogan: 1991. p. 864

41. Henderson BE, Feigelson HS. Hormonal carcinogenesis. Carcinogenesis. 2000;21:427-33.

42. Mizrachi D, Auchus RJ. Androgens, estrogens and hydroxysteroid dehydrogenases. Mol Cell Endocrinol. 2009:301:37-42.

43. Nguyen PT, Conley AJ, Soboleva TK, Lee RS. Multilevel regulation of steroid synthesis and metabolism in the bovine placenta. Mol Reprod Dev. 2012;79: 239-54. 
44. Secky L, Svoboda M, Klameth L, Bajna E, Hamilton G, Zeillinger R, et al. The sulfatase pathway for estrogen formation: targets for the treatment and diagnosis of hormone-associated tumors. J Drug Delivery. 2013; 2013:1-13.

45. Ahmad N, Kumar R. Steroid hormone receptors in cancer development: a target for cancer therapeutics. Cancer Lett. 2011;300:1-9.

46. Africander D, Storbeck KH. Steroid metabolism in breast cancer: Where are we and what are we missing? Mol Cell Endocrinol. 2018:5:86-97.

47. Mcnamara KM, Sasano H. The intracrinology of breast cancer. J Steroid Biochem Mol Biol. 2015;145:172-8.

48. Caceres S, Monsalve B, Peña L, Andres PJ, Alonso-Diez A, Illera MJ, et al. In vitro and in vivo effect of flutamide on steroid hormone secretion in canine and human inflammatory breast câncer cell lines. Vet Comp Oncol. 2018;16: $148-58$.

49. Cooper RL, Stoker TE, Tyrey L, Goldman JM, McElroy WK. Atrazine disrupts the hypothalamic control of pituitary-ovarian function. Toxicol Sci. 2000;53: 297-307.

50. Scarpin KM, Graham JD, Mote PA, Clarke CL. Progesterone action in human tissues: regulation by progesterone receptor (PR) isoform expression, nuclear positioning and coregulator expression. Nucl Recept Signal. 2009;7:e009.

51. Hickey TE, Robinson JL, Carroll JS, Tilley WD. Minireview. The androgen receptor in breast tissues: growth inhibitor, tumor suppressor. oncogene? Mol Endocrinol. 2012:26:1252-67.

52. Macedo LF, Guo Z, Tilghman SL, Sabnis GJ, Qiu Y, Brodie A. Role of androgens on MCF-7 breast cancer cell growth and on the inhibitory effect of letrozole. Cancer Res. 2006;66:7775-82.

\section{Publisher's Note}

Springer Nature remains neutral with regard to jurisdictional claims in published maps and institutional affiliations.

Ready to submit your research? Choose BMC and benefit from:

- fast, convenient online submission

- thorough peer review by experienced researchers in your field

- rapid publication on acceptance

- support for research data, including large and complex data types

- gold Open Access which fosters wider collaboration and increased citations

- maximum visibility for your research: over $100 \mathrm{M}$ website views per year

At $\mathrm{BMC}$, research is always in progress.

Learn more biomedcentral.com/submissions 